\title{
Effects of protein levels on growth and laying performance of the Malawian indigenous chicken
}

\begin{abstract}
The present study was conducted on growth and laying performance of indigenous chicken fed ration with different crude protein at Bunda campus students' farm. Nutrition remains one of the challenges that indigenous chickens experience under smallholder management system. The birds are dependent on scavenging feed resources which is associated with inadequate nutrition and chickens sometimes are supplemented with maize bran and left over's depending on the availability. Little has been done to determine the nutrition requirements of indigenous chickens. Therefore, the objective of this study was to evaluate effects of different protein levels on growth and laying performance of IC specifically to determine optimal protein requirement of indigenous chickens and assessing the growth and laying performance of the indigenous chicken. The study used repeated measure design where 7 day old chickens weighing $590 \pm 73 \mathrm{~g}$ were randomly allocated to diets containing different levels of proteins and each pen contained 13 chicks each. The diets were fed to the chicks at $\mathrm{ad} \mathrm{lib}$ and the amount given increased with the increase in the growth of the chickens. Water was also provided at ad lib. The collected data were analyzed using mixed model of SAS 2010. Significance was declared at $\mathrm{P}<0.05$ and means were separated using PDFF option of SAS software. In addition, SPSS software was used to compare the means. The results from the study have shown that there was an increase $(\mathrm{P}<0.05)$ in live weight in the chickens fed $180 \mathrm{~g} / \mathrm{kg} \mathrm{CP}$ compared to those fed 170 and $190 \mathrm{~g} /$ $\mathrm{kg} \mathrm{CP}$. laying percentage was high in chicken fed $18 \mathrm{~g} / \mathrm{kg} \mathrm{CP}$ and Egg weight with increasing from 35.93-43.18 with decrease in protein levels $(\mathrm{P}<0.05)$. The diet that contained $17 \mathrm{~g} / \mathrm{kg}$ had the highest egg weight compared to the other two diets.
\end{abstract}

Keywords: egg weight, growth rate, laying percentage, rations, weight at laying
Volume 2 Issue 6 - 2017 Wisdom Kalinda, Jonathan Tanganyika
Lilongwe University of Agriculture and Natural Resources,
Malawi

Correspondence: Jonathan Tanganyika, Animal Science Department, Bunda campus, Lilongwe University of Agriculture and Natural Resources (LUANAR), PO Box 219, Lilongwe, Malawi,Tel 265-993 494 774, Email jtanganyika@gmail.com

Received: July 12, 2017 | Published: December 20, 2017

\section{Introduction}

In Malawi, just like any other country, nutrition remains one of the challenges that indigenous chickens experience under smallholder management system. The birds are dependent on scavenging feed resources which is inadequate and chickens sometimes are supplemented with maize bran and left over's depending on the availability. This results in low productivity in indigenous chickens. Indigenous chickens play important role in socio-economic status of rural people in developing countries. ${ }^{1}$ Nearly all rural and peri urban families in Malawi keep small flock of free range chickens. The wide distributions of IC among household indigenous chickens make greatest contribution to household food security and therefore provide most of the protein in villages in form of eggs and meat. Small land and low capital requirement makes the chickens appropriate for resource poor farmers and their communities. ${ }^{2}$ Nutritional requirements of chickens are influenced by genotype and body size. The provision of supplemental feed in scavenging chicken production has direct influence on productivity of scavenging indigenous chickens, but little information is available on the strategies to be used to supplement scavenging chickens. ${ }^{3}$ In Malawi, nutrition remains one of the challenges that indigenous chickens experience under smallholder management system. The birds depend on scavenging feed resources and occasional supplementation with kitchen leftovers, cereal bran and small amounts of cereal grains which do not provide the required nutrients for normal activities and growth. However, little has been done to find out the nutrition requirements of the indigenous chickens in Malawi. Therefore, the current study aims at determining the optimal crude protein that can improve the performance of the IC in terms of growth and egg production.

\section{Materials and methods}

\section{Study area}

The experiment was conducted at Students farm, Bunda campus of the Lilongwe University of Agriculture and Natural Resources (LUANAR). Thirty nine chicks were used in this study. The chicks were grouped into 3 groups of 13 chicks each.

\section{Experimental design}

Repeated measure design where 7 day old chickens weighing $590 \pm 73 \mathrm{~g}$ were randomly allocated to diets containing different levels of proteins. The diets were fed to the chicks at ad lib and the amount given increased with the increase in the growth of the chickens. Water was also provided at ad lib (Table 1)

Table I Feeding regime

\begin{tabular}{lll}
\hline Weeks & Diet & Amount/Pen(kg) \\
\hline $0-6$ & Chick Mash 20\% CP & $\mathrm{I}$ \\
10-Jun & Growers Mash (17, 18\&19\% CP) & $\mathrm{I}$ \\
14-Oct & Growers Mash & 1.5 \\
$14-17$ & Growers Mash & 2 \\
$17-20$ & Growers Mash & 3 \\
\hline
\end{tabular}

\section{Composition of experimental rations}

The ration was formulated using Pearson square method and using ration formulation and feed guides according to ${ }^{4}$ (Table 2). 
Diet $1=17 \% C P ;$ Diet $2=18 \% C P$ and Diet $3=19 \% C P$

Table 2 Composition of experimental diets

\begin{tabular}{llll}
\hline Ingredients (KG) & Diet I & Diet 2 & Diet 3 \\
\hline Maize & 51.21 & 49.18 & 47.16 \\
Maize bran & 20.92 & 20.09 & 19.26 \\
Soy bean & 21.09 & 23.63 & 26.16 \\
Fish meal & 2.64 & 2.95 & 3.27 \\
Salt & 0.3 & 0.3 & 0.3 \\
Premix & 0.3 & 0.3 & 0.3 \\
MCP & 1.5 & 1.5 & 1.5 \\
Lime & 2 & 2 & 2 \\
DL Methionine & 0.05 & 0.05 & 0.05 \\
Total & 100 & 100 & 100 \\
\hline
\end{tabular}

\section{Data collection and analysis}

The data which were collected include weekly live weight, weight at laying, number of egg laid per pen and weight of the eggs. The collected data was analyzed using mixed model of SAS 2010 software. Significance was declared at $\mathrm{P}<0.05$ and means were separated using PDFF option of SAS software. In addition, SPSS software was used to compare the means.

\section{Statistical model}

$$
Y_{i j t}=\mu+\alpha_{i}+d_{j(\mathrm{i})}+\gamma_{t}+(\mathrm{ya})_{i t}+E_{i j t}
$$

Where

$y_{i j t}=$ live body weight measured at time the jth chickens assigned to the $\mathrm{i}^{\text {th }}$ diet,

$\mu=$ the overall mean effect, $\alpha_{i}=$ the $\mathrm{i}^{\text {th }}$ fixed diet effect,

$d_{j(i)}=$ the random effect of the $\mathrm{j}^{\text {th }}$ chickens within the ith diet,

$\gamma_{t}=$ the fixed $\mathrm{t}^{\text {th }}$ time effect when the measurement was taken,

$(\gamma \alpha)_{i t}=$ the fixed interaction effect between diet and time,

$E_{i j t}=$ the random error

\section{Results}

\section{Growth performance of the indigenous chickens}

Table 3 shows significant differences in mean live weight among different rations $(\mathrm{P}<0.05)$. Thus live weight was affected $(\mathrm{P}<0.05)$ by the rations (Table 3 ).

Table 3 Fixed model effect

\begin{tabular}{ll}
\hline Effect & P value \\
\hline Diet & 0.0901 \\
Week* Diet & $<.0001$ \\
Initial Weight & 0.0061 \\
\hline
\end{tabular}

Table 4 showed that chickens that were fed the diet containing $180 \mathrm{~g} / \mathrm{kg}$ DM gained more weight compared to those fed $170 \mathrm{~g} / \mathrm{kg}$ $\mathrm{DM}$ and $190 \mathrm{~g} / \mathrm{kg}$ from $8-10$ week. The diet of $180 \mathrm{~g} / \mathrm{kg}$ DM resulted in superior weights at week 8 and week 10 because the ration contained (\%) Crude protein which is the required CP for growth and maintenance. Since there was no further improvement in growth rate beyond $180 \mathrm{~g} / \mathrm{kg} \mathrm{DM}$, it can be concluded that that $190 \mathrm{~g} / \mathrm{kg}$ DM was above the requirement for this group of chickens (Table 4).

$\mathrm{SEM}=$ Standard error of the mean

${ }^{a b}$ Means with different superscripts along the column are significantly different $(\mathrm{P}<0.05)$

Table 4 Least square means of interaction between level of protein in the diet and time of pullets of Malawi indigenous chickens

\begin{tabular}{lllllllll}
\hline \multirow{2}{*}{ CP, g/kg DM } & \multicolumn{2}{l}{ Time } & \multicolumn{1}{c}{} & & & & \\
\cline { 2 - 7 } & Week8 & Week 9 & Week 10 & Week II & Week I2 & Week I3 & Point of lay & SEM \\
\hline 170 & 615.65 & $744.15^{\mathrm{a}}$ & $849.65^{\mathrm{a}}$ & 931.48 & 964.98 & $985.81^{\mathrm{a}}$ & 1020.48 & 27.52 \\
180 & 673.93 & $870.26^{\mathrm{b}}$ & $964.93^{\mathrm{b}}$ & 1018.59 & 1049.93 & $1092.59^{\mathrm{ab}}$ & 1107.93 & 39.33 \\
190 & 687.39 & $800.89^{\mathrm{a}}$ & $893.56^{\mathrm{a}}$ & 959.06 & 1002.06 & $1033.56^{\mathrm{b}}$ & 1050.89 & 27.74 \\
\hline
\end{tabular}

\section{Laying performance of the indigenous chicken}

There was a relationship between laying percentage and weight

(Table 5). The chicken fed $17 \mathrm{~g} / \mathrm{kg}$ CP laid few eggs but the weights were high $(\mathrm{P}<0.05)$ compared to the other diets. ${ }^{\text {ab }}$ Means with different superscripts are significantly different $(\mathrm{P}<0.05)$

Table 5 Influence of protein level on laying and egg weight

\begin{tabular}{lccccc}
\hline \multicolumn{7}{l}{ Treatment (g/kg CP Feed on DM) } & & & \\
\hline & - & - & - & 170 & - \\
Weight at laying $(\mathrm{g})$ & - & $1020.48^{\mathrm{b}}$ & $1107.93^{\mathrm{a}}$ & $1050.89^{\mathrm{b}}$ & - \\
Laying \% & - & $78.57^{\mathrm{b}}$ & - & $107.14^{\mathrm{a}}$ & $85.7 \mathrm{I}^{\mathrm{b}}$ \\
Egg weight $(\mathrm{g})$ & $43.18^{\mathrm{a}}$ & $35.93^{\mathrm{b}}$ & - & $36.33^{\mathrm{b}}$ & - \\
\hline
\end{tabular}




\section{Discussion}

According to Bikker ${ }^{5}$ feeding indigenous chickens above the protein requirements does not result in an increase in protein deposition, but nitrogen excretion through the urine which increases rapidly. The chickens that fed $170 \mathrm{~g} / \mathrm{kg} \mathrm{DM}$ also met the requirement of the chicken but the weight gain was low as compared to $180 \mathrm{~g} / \mathrm{kg}$. Similarly, Mbajiorgu et al. found that during a 7-13 weeks growth stage, South African Venda chickens fed diets containing 18-22\% CP grew faster than those offered a diet of $16-17 \%$ CP. Egg production, expressed as laying percentage was $78.57-107.14 \%$. This was similar $(\mathrm{P}>0.05)$ between chickens fed diet 1 and 3 but higher $(\mathrm{P}<0.05)$ for those on diet 2. Egg weight increased $(\mathrm{P}<0.05)$ between diets 1 and 3. Diets 2 and 3 had similar egg weights $(P>0.05) 35.93 \mathrm{~g}$ and $36.33 \mathrm{~g}$ respectively but different egg production $(\mathrm{P}<0.05)$. Laying percentage was lowest $(78.57 \%)$ for diet 1 compared to the other two diets. Weight at laying was similar between chickens on diet 1 and 3 $(\mathrm{P}>0.05)$. Chicken on diet 2 had highest weight at the start of laying. The results showed that weight at laying of the chickens were similar to those offered diet 1 and 3 this is an indication that all the rations met the requirement for maintenance of the chickens. Diet 1 and 3 were not significantly different at $\mathrm{P}>0.05$ confidence interval. The chicken on diet 2 registered high laying percent compared to the rest. This could have been due to the difference in the number of the hens in the pens. The mortality rate was higher during the first week, resulting in an imbalance between the females in the pens. Diet 1 had lowest laying percentage but the ration had an impact on the egg weight. The results agree with 9 NRC (1984) reports that the amino acid concentration of typical maize-soya diets (16 and $18 \% \mathrm{CP})$ meets the requirements of growing layer chickens. ${ }^{6}$ The drop in live weight at the starting of laying point of the chickens could be attributed to more nutrients being diverted from growth to egg production. The study by Tuitoek ${ }^{7}$ found that altering dietary protein concentrations between $10-14 \%$ CP affected egg weight while $\mathrm{Cho}^{8}$ reported no increase in egg weight in commercial layers offered diets with protein between $15 \%$ and $19.5 \%$ CP. Gous ${ }^{9}$ reported that the effect of altering the dietary amino acid concentrations was more severe on egg production than on egg weight.

\section{Conclusion}

The study has shown that the diet 2 which contained $18 \% \mathrm{CP}$ had impact on the weight gain of the indigenous chickens $(\mathrm{P}<0.05)$ and also diet 1 with $17 \% \mathrm{CP}$ had an effect $(\mathrm{P}<0.05)$. Diet 2 should be fed to the chickens up to the point of laying whereas diet 1 , should be used during the laying period for increased egg weight and size. This information will be useful in the formulation of indigenous layer chicken diets with the appropriate protein content.

\section{Acknowledgements}

This study was in partial fulfillment of the requirement for the degree of Bachelor of Science in Animal Science and the author would like to express deep and profound gratitude to $\mathrm{Mr}$ G Chingala and Mr J Tanganyika, the project supervisors, Professor JP Mtimuni and Mr D Chiumia the research project coordinators for their high profile assistance throughout the course of the project.

\section{Conflict of interest}

The author declares no conflict of interest.

\section{References}

1. Alders R. Poultry for profit and pleasure. Italy: FAO Diversification; 2004.

2. Lwesya HJ. Management intervention measures for indigenous chicken in smallholder farming system in lilongwe west rural development project. Malawi: University of Malawi; 2003.

3. Okitoi LO, Kabuage LW, Muinga RW, et al. The performance response of scavenging chickens to nutrient intake from scavenge able resources and from supplementation with energy and protein. Livestock Research for Rural Development. 2009;21(10):1-9.

4. Mtimuni JP. Ration Formulation and Feed Guide. 2nd ed. Malawi: Blantyre printing and publishing Company Limited; 2011.

5. Bikker P, Verstegen MWA, Tamminga S. Partitioning of dietary nitrogen between body components and waste in young pigs. Netherlands Journal of Agricultural Science. 1994;42:37-45.

6. NRC. Nutrient requirements of poultry. 9th ed. USA: National Academy Press; 1994. p. 61-79.

7. Kingori AM, Tuitoek JK, Muiruri HK, et al. Protein requirement of growing indigenous chicken during the 14-21 week growing period. South African Journal of Animal Science. 2003;33(2):78-82.

8. Cho YM, Shin IS, Yang CJ. Effects of feeding dried leftover food on productivity of laying hens. AJAS. 2017;17:518-522.

9. Gous RM, Kleyn FJ. Responses by laying hens to energy and amino acids. In: Cole DJA, Heresign W, editors. Recent Developments in Poultry Nutrition. 1989. 